12. A Stochastic Approach for the Analysis of Fault Trees With Priority AND Gates / Zhu P. et. al. // IEEE Transactions on Reliability. 2014. Vol. 63, Issue 2. P. 480-494. doi: http:// doi.org/10.1109/tr.2014.2313796

13. Approximate reliability of multi-state two-terminal networks by stochastic analysis / Zhu P. et. al. // IET Networks. 2017. Vol. 6, Issue 5. P. 116-124. doi: http://doi.org/10.1049/iet-net. 2017.0033
Stefanozych Tetyana, PhD, Associate Professor, Department of Mechanical Engineering, Lviv Polytechnic National University, Ukraine, e-mail: tetyana.o.stefanozych@lpnu.ua, ORCID: http:// orcid.org/0000-0002-8577-4755

Shcherbovskykh Serhiy, Doctor of Technical Sciences, Senior Researcher, Department of Computer-Aided Design, Lviv Polytechnic National University, Ukraine, e-mail: shcherbov@gmail.com, ORCID http://orcid.org/0000-0001-8535-733X

\title{
Radzinskaya $\mathbf{Y}$, DETERMINATION OF INVESTMENT Korniiets A. ACCURACY AND FORMATION OF INFORMATION SUPPLY OF GEOECOLOGICAL MONITORING OF USE OF LAND
}

Об’єктом дослідження є технологія визначення інвестиційної привабливості та формування інформачійного забезпечення геоекологічного моніторингу використання земель. Однією з найбільших проблем в сучасних підходах до визначення інвестиційної привабливості та геоекологічного стану використання земель є складність існуючих підходів та відсутність інформаційного забезпечення.

Розроблено методи до оиінки інвестииійної привабливості та геоекологічного стану використання земель. Ці методи дають можливість розробити заходи до комплексного зростання інвестииійної привабливості та визначення геоекологічного стану земель для формування методичних рекомендацій щодо підвищення ефективності використання земель. Запропоновані підходи мають аналітичний характер та базуються на методі аналізу ієрархій, результатах кореляційно-регресійного аналізу. На відміну від існуючих, вони дали змогу сформувати системне середовище для кількісної оцінки геоекологічного стану та використання земель.

В ході досліджень використовувалися просторовий, багатофакторний, рейтинговий та економічний підходи. Виявлено, що вказані підходи не мають чіткої послідовності та не в повній мірі визначають сучасні аспекти використання земель.

За розробленими методами до оцінки інвестииійної привабливості та геоекологічного стану використання земель запропоновано комплексний підхід. Він базується на результатах математичного моделювання та дає можливість отримати інтегральну оцінку геоекологічного стану використання земель.

Завдяки цьому дані розробки забезпечать оиінку земель та прийняття рімень з боку заиікавлених осіб на місцевому, регіональному та державному рівнях. Розроблений інтегральний критерій дозволить підвищити рівень використання земель та забезпечить їх комплексну оцінку. Запропоновані рекомендації дадуть можливість чітко та обгрунтовано вплинути на рівень використання земель, та своєчасно його врегулювати. У порівнянні з відомими підходами, розроблений має комплексний характер та базується на послідовних етапах аналітичних розрахунків. Це забезпечує точність оцінки та виключає вплив об'єктивних факторів при визначенні інвестиційної привабливості та геоекологічного стану використання земель.

Ключові слова: інвестииійна привабливість земель, геоекологічний моніторинг, інформачійне забезпечення, використання земель.

\section{Introduction}

Creation of a favorable investment climate and geoecological state in the land sector directly determines the further development of both cities and regions and the country as a whole. The processes of development of cities and regions, first of all, are stipulated by the volume and rates of growth of investments in their lands, will change their structure and qualitative characteristics. Along with this, in most regions of Ukraine there are problems in balancing the environmental support for land use. Deepening of negative processes external and internal factors:

- degradation of natural ecosystems;

- loss of biodiversity;
- increase in the incidence of the population;

- global climate change;

- anthropogenic load on the natural environment;

- erosion;

- pollution;

- moistening and bogging of soils;

- decrease in efficiency of land use.

To solve the presented problems, geoecological monitoring systems are used, which are formed on the basis of information support for increasing the efficiency of land use, taking into account the influence of environmental factors. But, in most cases, the set of factors that directly shapes the investment attractiveness of the land and form the information support for geoecological monitoring of 
their use remains. The presented feature is determined by the complexity of the application of modern approaches and tools, the lack of information support, as well as the lack of an integral indicator of the assessment of investment attractiveness and the geoecological state of land use.

Therefore, under these conditions, there is a need to improve technology to determine the investment attractiveness and geoecological status of land use by developing a method and models to assess their impact. The method and models are based on the construction of multilevel systems of indicators, which make it possible to determine the integral investment indicator and create a basis for information support for geoecological monitoring of land use [1].

\section{The object of research and its technological audit}

The object of research is the technology of determining the investment attractiveness and the formation of information support for geoecological monitoring of land use.

In recent years, the volume of work on land valuation has been decreasing. According to the State Service of Ukraine for Geodesy, Cartography and Cadastre as of $01.01 .2018,28 \%$ of the land will require a normative monetary estimate, compared with the same period last year increased by 2.2 times [2].

At the same time, the reliability and completeness of information support for the formation and distribution of land is increasing. The reasonableness of the implementation of the areas of development of the territories is unsatisfactory, which reduces the investment attractiveness of the land.

At the same time, it is theoretically necessary to clarify the concept of geoecological monitoring of land use as a single system that takes into account environmental and land use factors. For the formation and implementation of geoecological monitoring, there is a need to develop information support based on the assessment and modeling of indicators of the geoecological state.

Thus, the solution of problems of formation of investment attractiveness and information support of geoecological monitoring of land use is an important problem, the solution of which will increase the efficiency of land use. It is proposed to solve this problem by developing methods for the integrated assessment of investment attractiveness and assessing the geoecological state of land use.

\section{The aim and objectives of research}

The aim of research is development of methods for determining investment attractiveness and geoecological monitoring of land use.

To achieve this aim it is necessary to:

1. Analyze the theoretical provisions for determining the investment attractiveness of lands and approaches to the formation of information support for geoecological monitoring of land use.

2. Determine the degree of the method of integral assessment of the investment attractiveness of lands and the method of integrated assessment of the geoecological state of land use.

3. Offer methodical recommendations for the growth of investment attractiveness and scientifically grounded recommendations on the formation of information support for geoecological monitoring of land use.

\section{Research of existing solutions of the problem}

A lot of scientists dealt with the rational use of land resources. So, the work [3] is devoted to the formation and distribution of land resources, but it does not investigate the features of individual land plots. At the same time, the authors of [4] determined the features of a particular land plot, but did not take into account the influence of regional features of investment indicators. An alternative option should be considered work [5], which combines the shortcomings of previous works, but solves the problems of using land resources only from the economic point of view.

Theoretical and methodological provisions for formation, distribution and evaluation of land are presented in [6-8]. Work [6] solves the issue of land evaluation only at the agglomeration level, but the work [7] provides a more indepth assessment, although it does not take into account the distribution of land by category. At the same time, the work [8] solves the issues of land evaluation and allocation, not including the issue of investment characteristics of a particular region.

In $[9,10]$ attention was paid to GIS-support in the assessment of the territories of settlements of Ukraine.

The solution of problematic issues in the formation and use of geoecological monitoring, the use of tools for its implementation, was also engaged in many scientists. Thus, in [11] zones of ecological influence of individual factors are clearly defined, although their groupings do not take into account the spatial characteristics of land use. The authors of [12] were more consistent in determining the ecological features of land use, but did not take into account the functional features of the geoecological state system. In [13] the shortcomings of the predecessors were generalized, but there were no questions of geoecological definition of groups of factors of influence on the use of the regions' lands.

The authors of $[14,15]$ investigated the natural and resource potential of Ukraine's sustainable development, but did not take into account the ecological characteristics of individual cities and regions. The fundamental foundations for the formation of an environmental monitoring system for land use are presented in [16, 17], however, the lack of consistent methods of geoecological monitoring of land requires further development. Thus, the results of the analysis lead to the conclusion that the solution of issues of rational use of land resources is an important issue of our time.

\section{Methods of research}

The development of a method for the integrated assessment of the investment attractiveness of lands is carried out on the basis of the implementation of successive stages in the definition of information support, the construction of a system of indicators and the definition of an integral criterion for the investment attractiveness of lands. Examining the directions within the proposed method, it should be pointed out that the creation of information support for assessing the influence of factors on the formation of investment attractiveness of land is carried out in accordance with the regulatory legal documents [18] and the technical features of land use. 
The definition and characterization of factors influencing the formation of the investment attractiveness of lands and the construction of a multi-level system of indicators is carried out on the basis of own developments [19].

The presented method is a sequence of steps that include: - development of information support for the implementation of an integrated assessment of the investment attractiveness of land;

- construction of a multilevel system of indicators based on the hierarchical method of classification (Fig. 1); - development of mathematical local models for assessing the level indicators and a model of the integral criterion of the investment attractiveness of lands.

The integral criterion of investment attractiveness of lands is determined by the model:

$$
I_{i}=I_{f}^{1}+I_{p}^{1}+I_{i n g}^{1}+I_{e}^{1},
$$

where $I_{f}^{1}, I_{p}^{1}, I_{i n g}^{1}, I_{e}^{1}$ - integral indicators of the first level of investment attractiveness of lands: functional-planning; territorial; engineering support and landscaping; environment, ecology and historical and cultural component.

Models are proposed for assessing the investment attractiveness of lands based on the use of analytical and hierarchy analysis methods, which allowed to formalize the influence of factors on the investment attractiveness of lands.

The second level of investment attractiveness of the lands was assessed by determining each group of indicators based on local models. Assessment of the first level of investment attractiveness of land is determined using local models that take into account the influence of groups of factors and weight coefficients that characterize the level of interaction between them by applying methods of analyzing hierarchies.
The ranges of values of the integral criterion, established by the scale of T. Saaty, were determined. They justify the level of investment attractiveness of lands.

The value of the integral criterion for the investment attractiveness of lands (0.891) was calculated, which allowed using it in the system of normative monetary evaluation of lands and create an information basis for the development of methodological recommendations for increasing the investment attractiveness of lands.

By the value of the integral criterion, integral indices of the potential investment attractiveness of urban lands are determined taking into account changes in the normative monetary estimation of the lands of settlements.

The level of investment attractiveness of the regional centers of Ukraine is determined (Table 1).

Table 1

Results of the definition of integrated indicators $I_{\text {in }}$ and $I_{\text {iny }}$ c. u.

\begin{tabular}{|c|c|c|c|c|c|c|c|}
\hline No. & City & $I_{\text {in }}$ & $I_{\text {iny }}$ & No. & City & $I_{\text {in }}$ & $I_{\text {iny }}$ \\
\hline 1 & Lviv & 2.144 & 3.662 & 12 & Zaporizhzhia & 1.899 & 3.099 \\
\hline 2 & Ivano-Frankivsk & 1.067 & 3.381 & 13 & hivne & 1.262 & 3.072 \\
\hline 3 & Ddesa & 1.810 & 3.337 & 14 & 5umy & 1.003 & 3.063 \\
\hline 4 & Vinnytsia & 1.380 & 3.266 & 15 & Mykolaiv & 0.997 & 3.040 \\
\hline 5 & Kyiv & 3.258 & 3.246 & 16 & Cherkasy & 0.924 & 2.996 \\
\hline 6 & Dnipro & 2.585 & 3.243 & 17 & Khmelnytskyi & 0.923 & 2.948 \\
\hline 7 & Lutsk & 1.032 & 3.225 & 18 & Poltava & 0.987 & 2.935 \\
\hline 8 & Kharkiv & 2.082 & 3.211 & 19 & Kirovohrad & 1.043 & 2.935 \\
\hline 9 & Chernihiv & 0.911 & 3.195 & 20 & Uzhhorod & 1.535 & 2.914 \\
\hline 10 & Zhytomyr & 1.346 & 3.168 & 21 & Kherson & 1.242 & 2.891 \\
\hline 11 & Ternopil & 0.961 & 3.102 & 22 & Chernivtsi & 1.188 & 2.859 \\
\hline
\end{tabular}

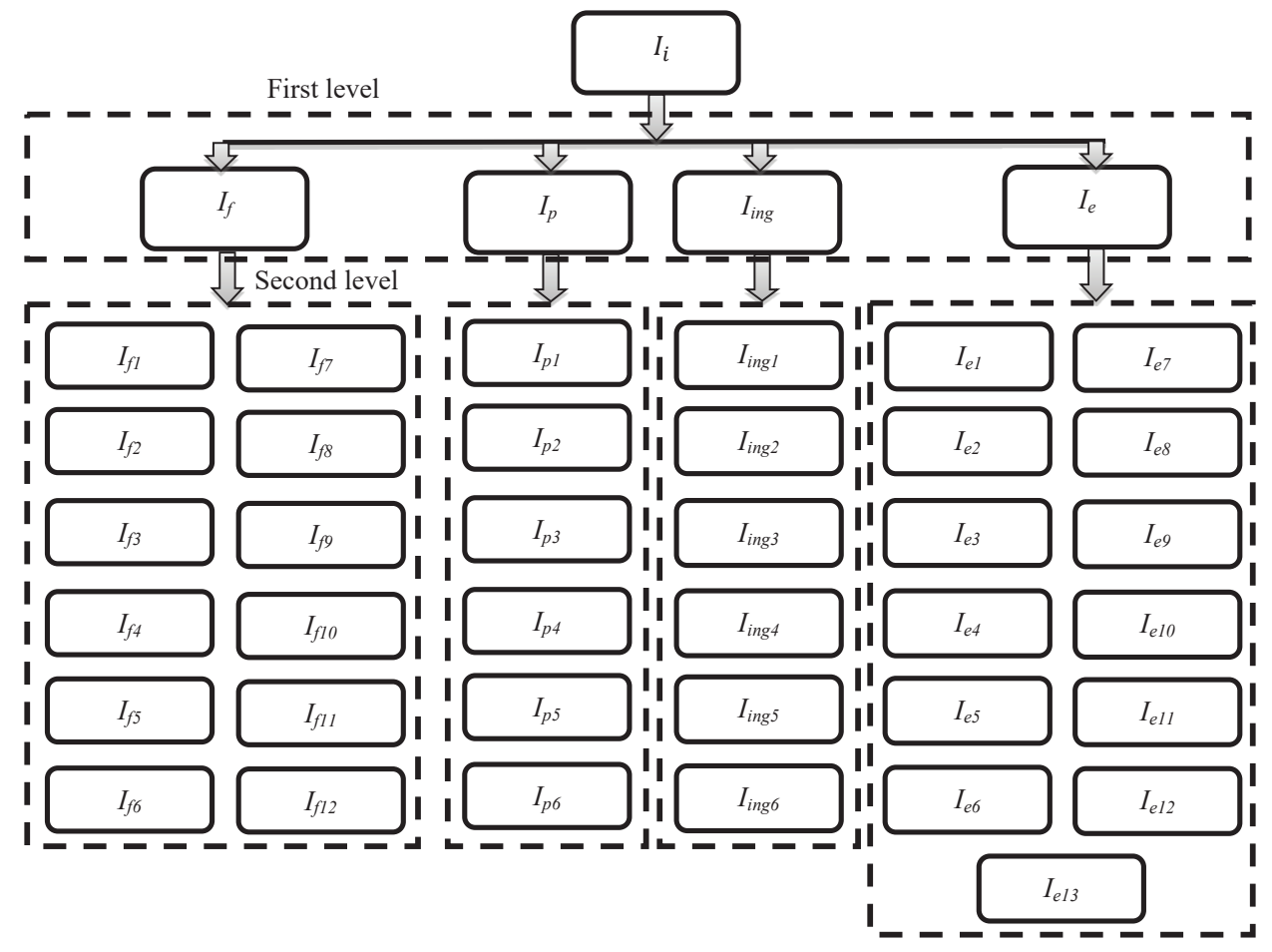

Fig. 1. Scheme of a two-level system of indicators that form an integral criterion of the investment attractiveness of lands $\left(I_{i}\right.$ - integral criterion of investment attractiveness; $I_{f}, I_{p}, I_{\text {ing }}, I_{e}$ - indicators of the first level; $\left.\left(I_{f i}\right) \in I_{f} ; i=\overline{1,12}\right)$ - tuple of functional-planning indicators; $\left.\left(I_{p i}\right) \in I_{p} ; i=\overline{1,6}\right)$ - tuple of territorial indicators; $\left.\left(I_{\text {ingi }}\right) \in I_{\text {ing }} ; i=\overline{1,6}\right)$ - tuple of indicators of engineering support and landscaping; $\left.\left(I_{e i}\right) \in I_{e} ; i=\overline{1,13}\right)$ - tuple of environmental indicators, ecology and historical and cultural component) 
The development of a method for the integrated assessment of the geoecological state of land use is carried out on the basis of certain ecological and land use indicators in a similar way. At the same time, expert assessment methods, analytical methods and hierarchy analysis methods are used to evaluate the presented indicators. The proposed methods form a comprehensive tool for the integrated assessment of the geoecological state of land use.

Formation of a method for assessing the geoecological state of the use of the region's lands is carried out on the basis of the implementation of the stages (Fig. 2).

Thus, the method of integral assessment of the investment attractiveness of lands as an element of technology based on the use of analytical, hierarchy analysis method and hierarchical classification method is proposed. This allowed to determine the integral criterion of investment attractiveness of lands and create an information basis for the development of guidelines for:

- increase of the investment attractiveness of lands,

taking into account the normative and legal;

- functional-planning, territorial, engineering support;

- level of landscaping;

- their ecological and historical and cultural status.

At the same time, the development of a method for assessing the geoecological state of land use includes a set of interrelated actions aimed at determining an integral indicator on the basis of which decisions are made to improve land use efficiency and appropriate measures are being developed. The development of this method has made it possible to determine a general indicator for creating a basis for the formation of information support for geoecological monitoring of land use.

\section{Research results}

As a result, an integral criterion for the investment attractiveness of lands has been identified, the significance of which indicates a high level of influence of the factors studied on its formation.

Forecasting the values of the integral criterion for improving the technology of determining the investment attractiveness of land and developing guidelines is based on:

- results of investment factors assessment;

- definition of an integral criterion of investment appeal of the earths of cities;

- data of the normative monetary estimation of lands and statistical indicators of investment attractiveness.

Methodological recommendations for increasing the investment attractiveness of lands are proposed. They are obtained from the assessment and modeling of integrated indicators of the investment attractiveness of lands based on the growth of functional and planning, territorial, engineering support and improvement, environment, ecology and historical and cultural components of land use.

The implementation of the method of integrated assessment of the geoecological state of land use is based on the use of an analytical method of analyzing hierarchies and expert assessments. This made it possible to determine the corresponding integral indicator for creating a system environment for the formation of information support for geoecological monitoring and decision-making for improving land use efficiency. It should be noted that the greatest impact on the implementation of functional areas of environmental use of land is carried out by environmental and resource indicators that determine the level of use of land resources, taking into account their environmental characteristics. At the same time, the criterion of environmental protection and indicators of the formation of land potential are reduced. This indicates that the use of land in the ecological aspect is associated with the level of resource use and their impact on the ecological state of the territories with non-systematic implementation of environmental measures and ignoring the opportunities for development of the territories [20].

As a result of the research, it has been established that investment information sources and indicators are determined by the lowest influence on the formation of information support for the use of lands. This is due to the fact that in modern land use conditions the investment component is characterized by information closeness and low level of information support for land use.

However, when implementing land projects and implementing land use, special attention is focused on cartographic and spatial information support. At the same time, statistical, townplanning and regulatory supports for land use are taken into account.

Fig. 2. Scheme for the formation of a method for assessing the geoecological state of land use 


\section{SWOT analysis of research results}

Strengths. Methods are developed to assess the investment attractiveness and geo-ecological status of land use, based on the creation of multi-level factor systems possible to develop measures for a comprehensive increase in investment attractiveness and to determine the geoecological state of lands for the development of methodological recommendations for improving the efficiency of land use and ensuring their sustainable development.

Weaknesses. In modern land use conditions, the investment component is characterized by information closeness and low level of information support for land use.

Opportunities. In the future, it is necessary to create a comprehensive method for assessing the use of land and to improve the existing system of land administration.

Threats. Threats include:

- lack of provision of information resources, statistical data;

- timely regulation of the legislative base;

- difficulty of providing for relations between different groups of participants in land use.

\section{Conclusions}

1. The theoretical provisions for determining the investment attractiveness of lands and approaches to the formation of information support for geoecological monitoring of land use are analyzed. As a result, the following imperfections of predecessor approaches are determined:

- there are no studies on issues of investment charac-

teristics of a particular region;

- environmental features of individual cities aren't considered;

- there are no consistent methods for geoecological monitoring of land.

2. The method of integral assessment of the investment attractiveness of lands and the method of integrated assessment of the geoecological state of land use have been determined step-by-step. This made it possible to comprehensively determine the growth of investment attractiveness and the geoecological state of the earths with the help of quantitative data of the integral indicators of the method and also to form and justify the stages of the methods, and to determine the features of their application.

3. Methodical recommendations for the growth of investment attractiveness have been determined and scientifically grounded recommendations on the formation of information support for geoecological monitoring of land use have been developed. They ensure the effectiveness of the integrated method and exclude objective data on the selection of factors by excluding expert estimates and using analytical data.

\section{References}

1. UNATED NATIONS: Inventory of Land Administration Systems in Europe and North Americ. London: Produced and published by HM Land Registry, behalf of the UNECE Working Party on Land Administration, 2005. URL: http://www.unece.org/ index.php?id=10952

2. Informatsiia pro normatyvnu hroshovu otsinku zemel naselenykh punktiv stanom na 01 sichnia 2016 roku ta 01 sichnia 2017 roku // Derzhavna sluzhba Ukrainy z pytan heodezii, kartohrafii ta kadastru. URL: http://land.gov.ua (Last accessed: 08.02.2017)
3. Khvesyk M. A. Instytutsionalne zabezpechennia zemlekorystuvannia: teoriia i praktyka: monograph. Kyiv: Knyzhkove vyd-vo NAU, 2006. $260 \mathrm{p}$

4. Larsson G. Land registration and Cadastral Systems: tools for land information and management. Esex: Longman Scientific and Technical, 1991. 387 p.

5. Perovych L. M., Hubar Yu. P. Otsinka nerukhomosti: textbook. Lviv: Vyd-vo Nats. un-tu «Lvivska politekhnika», 2016. 300 p.

6. A survey of scheduling problems with setup times or costs Allahverdi A. et. al. // European Journal of Operational Research. 2008. Vol. 187, Issue 3. P. 985-1032. doi: http://doi.org/ 10.1016/j.ejor.2006.06.060

7. The use of $3 \mathrm{~d}$ city models form oblique images on land administration / Bakici S. et. al. // ISPRS Annals of Photogrammetry, Remote Sensing and Spatial Information Sciences. 2017. Vol. IV-4/W4. P. 117-121. doi: http://doi.org/10.5194/ isprs-annals-iv-4-w4-117-2017

8. Sallivan A. O. Chetvertoe izdanie «Ekonomika goroda». Moscow: INFRA, 2002. 705 p

9. Mamonov K. A., Nesterenko S. H., Viatkin K. I. HIS-zabezpechennia u ratsionalnomu vykorystanni zemelnykh resursiv miskoi zabudovy // Naukovyi visnyk budivnytstva. 2016. Vol. 86, Issue 4. P. 323.

10. Palekha Yu. N. Osobennosti ispol'zovaniya GIS-tekhnologiy v otsenke territoriy naselennykh punktov Ukrainy // Uchenye zapiski Tavricheskogo natsional'nogo universiteta im. V. V. Vernadskogo. Geografiya. 2003. Vol. 16, Issue 55. P. 125-132.

11. Heoinformatsiini systemy ekolohichnoi bezpeky obiektiv naftohazovoho kompleksu: proceedings / Adamenko O. M. et. al. Kyiv: Znannia, 2003. P. 28-30.

12. Bilashenko O. H. Vyznachennia heoekolohichnoho stanu tekhnohenno-navantazhenykh terytorii za kompleksom heofizychnykh danykh: PhD thesis. Derzhavnyi Vyshchyi navchalnyi zaklad «Natsionalnyi hirnychyi universytet». Dnipropetrovsk, 2015. 176 p.

13. Land Quality Indicators. World Bank Discussion Paper No. 315 / Pieri C. et. al. Washington: World Bank, 1995. 51 p.

14. Pryrodno-resursnyi potentsial staloho rozvytku Ukrainy / Danylyshyn B. M. et. al. Kyiv: RVPS Ukrainy, 1999. 716 p.

15. Trysniuk V. M. Heoekolohichnyi monitorynh Podilskykh Tov-tr v mezhakh Husiatynskoho raionu Ternopilskoi oblasti: PhD thesis. Chernivetskyi natsionalnyi universytet imeni Yuriia Fedkovycha. Chernivtsi, 2004.

16. Surface Soil Physical Properties After Twelve Years of Dryland No-Till Management / Shaver T. M. et. al. // Soil Science Society of America Journal. 2002. Vol. 66, Issue 4. P. 1296-1303. doi: http://doi.org/10.2136/sssaj2002.1296

17. Novakovskyi L. Ya., Tretiak A. M., Dobriak D. S. Zemelna reforma i zemleustrii v Ukraini. Kyiv: IZU UAAN, 2001. 138 p.

18. Sakala W. D., Kumwenda J. D. T., Saka A. R. The Potential of Green Manures to Increase Soil Fertility and Maize Yields in Malawi // Biological Agriculture \& Horticulture. 2003. Vol. 21, Issue 2. P. 121-130. doi: http://doi.org/ $10.1080 / 01448765.2003 .9755257$

19. Radzinska Yu. B. Teoretychni pidkhody shchodo otsinky investytsiinoi pryvablyvosti zemel mist // Suchasni tekhnolohii ta metody rozrakhunkiv u budivnytstvi. 2017. Issue 8. P. 216-221.

20. Impact of direct sowing mulch-based cropping systems on soil carbon, soil erosion and maize yield / Scopel E. et. al. // Agronomy for Sustainable Development. 2005. Vol. 25, Issue 4. P. 425-432. doi: http://doi.org/10.1051/agro:2005041

Radzinskaya Yuliia, Senior Lecturer, Department of Land Ad ministration and Geographic Information Systems, O. M. Beketor National University of Urban Economy in Kharkiv, Ukraine, e-mail: radzinskayayb@gmail.com, ORCID: http://orcid.org/0000-00021661-7975

Korniiets Anna, Postgraduate Student, Department of Land Administration and Geographic Information Systems, O. M. Beketov National University of Urban Economy in Kharkiv, Ukraine, e-mail: annakorniiets@gmail.com, ORCID: http://orcid.org/00000002-5762-387X 